\title{
The model of understanding education and lifelong learning in Turkish modernization of Ahmet Midhat ${ }^{1}$
}

\author{
Ramazan Enser ${ }^{2}$
}

\begin{abstract}
The literary works of Ahmet Midhat Efendi like novels, stories, drama, travel writings in addition to subjects over education, pedagogy, sociology, philosophy and other fields have taken a vital place in Turkish literature. While the first Turkish modernizers gave priority to take the country out of the hard situation by reforming military and political areas, Ahmet Midhat argued that the social change and transformation can be achieved by educating individuals. Ahmet Midhat who tried to improve his educational background by spending personal efforts, always attempted to make education a constant activity for himself and people around him even during the times he was outside Istanbul for journalism, writing, familial issues and other reasons.

The purpose of this paper is to show what kind of social benefit based theoretical methods were employed to concretize Ahmet Midhat's educational view in his novels and stories by associating it with lifelong learning.

In this study, the aim is to show by which theoretical methods lifelong learning is concretized in Ahmet Midhat's novels and stories that are based on social benefit, and to demonstrate its relationship with educational conception.

In the study, Ahmet Midhat's novels which are especially handling directly family and education subjects like "Çingene", "Felatun Bey ile Rakım Efendi", "Diplomalı Kız" are taken as basis. To achieve this aim, a survey research has been made while scanning the works mentioned above. Moreover, the relationship between the given data and lifelong education has been tried to be put forward.

At the end of the paper, Ahmet Midhat Efendi's novels have been examined and it's been evident that his lifelong learning approach is enough for educational process. Ahmet Midhat who aimed to build his own audience and to educate them has achieved two things in his novels: Firstly, the idealized characters told in Midhat's novels and stories, who tried improving degree of their knowledge and enriching their lives, reached the success in different fields were given in theoretical level. This technique which is used by the author in his novels has an aesthetic basis as a social aspect of literature. Secondly, the author gives encyclopedic information to the audience by going out of the fictional text. Furthermore, since the author is using traditional storytelling as a way to establish a dialogue with the audience, it's obvious that he views the reader as the subject of the lifelong learning. His style which is criticized to be a dry didacticism is mostly originates from his perception of authorship, which is regarded as a school.
\end{abstract}

Keywords: Lifelong learning; Ahmet Midhat Efendi; modernization; Çingene, Felatun Bey ile Rakım Efendi, Diplomalı Kız.

\footnotetext{
${ }^{1} \mathrm{~A}$ part of this study was presented at 1st International Conference on Lifelong Education and Leadership at Olomouc University, Olomouc, Czech, on October 29-31, 2015.

${ }^{2}$ Lecturer, Sakarya University, Turkish teaching application and research center, renser@sakarya.edu.tr
} 
Enser, R. (2016). The model of understanding education and lifelong learning in Turkish modernization of Ahmet Midhat. International Journal of Human Sciences, 13(1), 436-450. doi:10.14687/ijhs.v13i1.3513

\section{Introduction}

\subsection{Ahmet Midhat and education}

Many ideas emerged after it was officially accepted with the Imperial Edict of Reorganization that the Ottoman Empire fell behind the West. Mutual effort of these ideas was for the country to get over the troubles the country was in. The strongest ideology formation of that time was the group named Young Ottomans. According to Young Ottomans, inspired by the French Revolution, and especially to Namik Kemal, things ensuring prosperity in Europe were freedom, equality and "science". Therefore, the key concepts of the solution necessary for us were a "constitution" that will ensure freedom and "education system" that will ensure science with its technique. The belief that the society would move forward with the science technical developments in the West were based on and with a new constitutional organization was explicitly dominant. (Moran, 1998:16)

New Ottomans felt the need for public support to gain strength by forming a public opinion against the government. With this objective, they used two tools to appeal to the public: newspaper and literature. They built the new order first on language to let the public hear their voice. Sinasi, by publishing Tasvir-i Efkar (Daily Newspaper) in 1862 to educate the public, purports to turn the place into an important school with a new concept of language and literature. Namik Kemal, since he has a more productive and actionist personality, tries to vocalize his ideas from a more vibrant pitch like poems, theater, novels with some in new types by crossing off the old type of literature.

Pioneers of Reform literature like Şinasi, Namık Kemal, Ahmet Midhat, Şemsettin Sami, Samipaşazade Sezai believed that the country would develop by appropriating some perceptions, concepts of the Western civilization to their own society. Especially Namik Kemal, since he believed that the real reason for the situation the country was in was autocracy, tried to handle politically concentrated concepts like freedom, equality constitutional government fearlessly.

Ahmet Midhat also had similar beliefs as Namik Kemal during the first years of his ideological life. He went through a change after he was arrested and exiled to Rhodes because of one of his writings published in İbret newspaper in 1873, and moved away from political statements and accepted education and development issues of the country as his life's priority.

Starting a frantic writing life after the exile, Ahmet Midhat used being a novelist and journalist for education; he did not think of influencing the public with political aims like Namik Kemal. He wanted to increase their culture level by giving them encyclopaedical information. He believed that increasing the cultural level of the public is a must for development. What he especially wanted to inoculate the public and what he praised most was hard work in trade and a successful business life. (Moran, 1998:16)

In line with this objective, Ahmet Midhat (1844-1912), wrote over two hundred books in many fields from education to history, pedagogy to sociology, economy to philosophy besides short stories and novels, and he also continued to be a journalist at the same time almost throughout his whole life as a writer.

Actually, as can also be seen in the experiences Ahmet Midhat had, topic of education is a field he was interested in, thought about, generated projects on since beginning of his youth. Since his family was not in good economic condition, during his apprenticeship times as a little kid in an herbalist shop, he observes what kinds of things the thing called ignorance made an individual and a society be deprived of and decides, with a big ambition, to get educated.

He finishes school also with the support of his mentor, Midhat Pasha; learns French in addition to Arabic and Persian. He reads whatever he comes across with passion and with the impact of his curious personality. 
Enser, R. (2016). The model of understanding education and lifelong learning in Turkish modernization of Ahmet Midhat. International Journal of Human Sciences, 13(1), 436-450. doi:10.14687/ijhs.v13i1.3513

Ahmet Midhat, while he was under the service of the Pasha in Bagdad, writes a serious of lesson books named "Hace-i-Evvel" for art school students. Again, while he was in exile in Rhodes, he builds the "Medrese-I-Suleymaniye" (Suleymaniye Theological School) for children who don't know how to read and write and teaches lessons according to teaching method he developed himself. (Okay, 1989: 101).

He, afterwards, transforms this teaching method into a book. This piece, named "Rehnuma-y1 Muallimin" (Teachers' Guide), becomes famous in Istanbul both in public schools and in nonMuslim schools. This book is written primarily for the purpose of being a guide for a teacher in school. Together with this, it is also suitable for heads of the families to use in their homes. Of the two published books, one of them is a teacher's guide and the other is a work book. Writer indicates that this work book will teach how to read and write to even children with low intelligence level in a short amount of time (three months). (Us, 1955: 104-105)

Ahmet Midhat writes an open letter to Midhat Pasha in the first and last issue of the newspaper named Devir he had the patent of and published on August 29, 1872. In the letter, after showing with examples how the country has fallen behind, he touches upon the need for education. He wants to relay the people's demands for education and civilizing on behalf of the people to Midhat Pasha. He indicates that other nations are going forward on the road to civilization, are reaching some targets, but our society, on the other hand, and is falling behind. He sadly expresses that everyone calls our society as "barbarians" because they see us as poor and ignorant. After that he makes these requests related to education and development from Midhat Pasha, who is the grand vizier of that period:

"Educate us, teach us art, make us rich, make us free. So much that we can say proudly that we are Ottomans. We want advancement hey Grand Vizier, we want advancement! You are going to find the means and designate. Then we will hold on to the means you will find. You make a school; it is our fault if we don't go there to get educated. You make factories, sample farms; it is our fault if we don't work. You grant us freedom; it is our fault if we abuse it." (Us, 1955: 46-47)

He writes and gives works in almost all fields with this objective. He also tries to handle education as the main issue in his novels and stories. He applies the "entertaining and educations" functions Namik Kemal imposes on theater to novels and stories.

Ahmet Midhat, merely devotes himself to educating the public with the pieces he writes. He wants to first accustom the society to read and then to carry it to a certain level regarding culture and ethics. Close to modernization thoughts of II. Abulhamit, he sees advancement in material and culture fields as more of a priority than freedom and regime issues. (Okay, 2008: 33)

According to Berna Moran, on the other hand, Ahmet Midhat sees novel as a tool that will take us to civilization by increasing the knowledge and culture level of the society (Moran 1998:10).

Ahmet Midhat summarizes that he did not just write Mr. Felatun and Rakım to entertain the reader with these words: "Authors always talk about possibilities. When reading them, one should both enjoy them and also be reborn with them" (Ahmet Midhat, 2000:138).

Social benefit is fundamental in Ahmet Midhat's stories and novels. To primarily make the Turkish individual get accustomed to reading, then to improve him in respect to culture and art comprise his fundamental point of action. (Albayrak, 2010:10)

Ahmet Midhat, tries to apply the "social benefit" principle by also pushing the potentials a fictional text offers. (Koç, 2009:391)

Ahmet Midhat tries to give literary works in a form the Turkish reader has not been accustomed to before. Novel first exists thanks to him; then it becomes popular afterwards. It can be said that a reader mass has transpired with Ahmet Midhat. According to Tanpinar, lives of small city people 
Enser, R. (2016). The model of understanding education and lifelong learning in Turkish modernization of Ahmet Midhat. International Journal of Human Sciences, 13(1), 436-450. doi:10.14687/ijhs.v13i1.3513

change with Ahmet Midhat's books. Books are read and discussed at homes during relaxation times. Tanpinar says like this: "Midhat taught our society to read novels. It must be confessed that, he stayed devoted to work he did until the end and tried to fill this time throughout his life. He nurtured the reader mass he always considered as his family in some way continuously like a giant with novels, newspaper articles, information works brought down to the understanding level of the public." (459-460).

Being a defender of modernist aesthetics, Tanpinar criticizes Midhat making colloquialism a wording in written language and writing his works in this language. He pleads that Namik Kemal also takes social benefit as the basis but he always appeals to the intellectual mass but Ahmed Midhat has never been able to go up to this level and he ruthlessly adds: "he has no art, he always has good wishes towards the society" (456)

For Ahmet Midhat to handle every subject as a means for education has caused criticisms in a literary sense as can also be seen above. Actually, he is also aware of the situation and is not bothered from this. He expresses that since the period lived in has different priorities, living conditions do not make it possible to 'make literature', and that he left literature to Hamids, Ekrems (Yazg1ç, 1940: 25). As can also be understood from here, it is observed that Midhat's concept of being a writer which gets criticized is a conscious preference.

\subsection{Lifelong learning and Ahmet Midhat}

Human kind has rearranged his life style and future as the result of each development he experienced by keeping this changes in mind. Keeping up with improvement in individual and social means due to very rapid advancement with technological developments experienced especially within the last century is getting harder each day. With this objective, the European Union is working on some solution proposals since the last quarter of the $20^{\text {th }}$ century for individuals and societies to prepare for the future faced with experienced fast changes with fewer problems. One of the concepts that began to gain importance during this process is lifelong learning.

One of the first significant meetings where lifelong learning was handled is the UNESCO General Conference dated 1976. In this conference, the necessity to accept education as a process that needs to continue throughout life by restructuring the education system was emphasized. The conclusion that, individual centered structure must be established with new regulations for men and women to continue their education by themselves was reached (DTP, 2009).

Lifelong learning in the European Committee's Adult Education Glossary of Terms (2008) was described as all kinds of learning activity assumed throughout life that results in improving knowledge, technical knowledge, skills, competence and abilities due to personal, social or occupational reasons (Brooks \& Burton, 2008:7).

Also in the Eighth Five Year Development Plan, by indicating that learning cannot be restricted to formal education, that it must cover the whole life of an individual; these are said regarding lifelong learning: Lifelong learning covers formal, non-formal and lean education individuals carry on in all parts of their lives to ensure the biggest development in their private, family, social and occupational lives." (DP, 2001: 14).

Again in the same document, it is indicated that lifelong learning has three fundamental functions: First, to ensure personal development of individuals by focusing on active learning potential of individuals; second, to ensure social integration by contributing to equal opportunity of individuals and by strengthening democratic basis of the society; and third, to increase efficiency, production and to ensure contribution to economic growth by developing equal opportunity according to skill fields (DPT, 2001: 15). 
Enser, R. (2016). The model of understanding education and lifelong learning in Turkish modernization of Ahmet Midhat. International Journal of Human Sciences, 13(1), 436-450. doi:10.14687/ijhs.v13i1.3513

At the Commission of the European Communities, 2006 also, it was indicated that lifelong learning has three fundamental functions: to contribute to economic development, to ensure individuals' personal development and their realization of themselves and lastly, to raise individuals who will actualize socialization and democratic consciousness as an act (Commission of the European Communities, 2006).

On the Lifelong learning Strategy Document Ministry of National Education published in 2009, on the other hand, lifelong learning is described as all kinds of educational activities an individual participates throughout his/her life to develop his/her knowledge, skills, interests and proficiencies related to personal, social and staffing approach (DPT, 2009).

By emphasizing that lifelong learning also covers the knowledge and skills gained besides formal and non-formal education, it was expressed that lifelong learning cannot be subject to any restriction regarding age, gender, socio-economic status and education level. In addition, it was elaborated that lifelong learning must be seen as a continuous and planned activity that supports gaining of knowledge, understanding and skills that will ensure occupational and social successes of individuals, communities and the whole society (DPT, 2009).

In the report, the objective of lifelong learning is said to make it possible for individuals to actively participate in all stages of economic and social life to be able to adapt to information society and for them to control their lives better within this society (DPT, 2009).

Although lifelong learning comes out as the result of the person's self-motivation, it can be said that changing life styles and occupational needs have more impact on this. In this respect, emphasis is put on the tight bond between lifelong learning and employment issue caused by changing market conditions (Chapman \& Aspin, 1997; Tr.: Toprak-Erdoğan), (Hollanders \& Soete, 2010; Tr.: Toprak-Erdoğan).

One of the reasons lifelong learning has gained importance in especially the European countries having a developed social structure and among developing countries is the changing demographic structure. Since rapidly aging population in the mentioned countries makes adaptation to changing social structure difficult, it also brings out employment issues (Knapper \& Cropley, 2000; Tr.: Toprak- Erdoğan). In order to minimize these problems, lifelong learning model was introduced for education to continue throughout the lives of individuals besides its formal and non-formal forms. Relation between lifelong learning and employment is an indicator of the political side of the topic.

Ahmet Midhat lived during a period when formal and non-formal education had not been fully institutionalized yet, even the level of literacy was extremely low. Related to educational issues; for the country to be far behind the technical and technological level the West had reached brought many questions and issues in political field as well. As also mentioned above, since Ahmet Midhat was a child of a tradesman from a low income level, he grew up in difficult life conditions. Thus, he had the opportunity to see the problems the country was going through more internally. Ahmet Midhat, just like II. Abdülhamit, also believed primary solution to social and political problems went through an educational mobilization. In this respect, while he struggled for formal education to become widespread on one hand; on the other hand, he transformed journalism and authorship to merely a school by creating a serious reader mass.

Trying to develop himself with enormous curiosity and passion all through his life, one of the primary reasons of Ahmet Midhat's productivity in his writing life is his effort to make education of his reader mass continuous. This is an indication that the author is trying to actually apply lifelong learning both in his own life and on his readers.

Primary objective of Ahmet Midhat's education concept is an 'individual' having the competencies to solve his/her own problems. He believes, individuals, who make learning one of the objectives 
of their lives after their formal education as well, will ensure social development besides development of their own lives. He believes difficulties the country is facing both inside and in international conjuncture cannot be solved by changing the governing method, the primary target in this subject goes through education. In this respect, education understanding of Ahmet Midhat shows parallelism objectives indicated in both the Commission of the European Communities, 2006 and also the Eighth Five Year Development Plan published in 2001 (DPT, 2001: 14).

\section{Method}

\subsection{Research model}

In this study, data related to lifelong learning in Ahmet Midhat's Çingene(The Gypsy), Diplomalı Kız (Girl with a Diploma) and Felatun Bey ile Rakım Efendi (Mr. Felatun and Rakim) named novels were tried to be determined. In respect with this objective, data in the novels in subject were determined by using qualitative research approach.

\subsection{Collection of data}

Findings in this study were obtained by making text analyses. In this study, Felatun Bey İle Rakım Efendi novel partaking in volume named All The Works of Ahmet Midhat Novels I (Prepared by: Kazım Yetiş, Necat Birinci, M. Fatih Andi) published by Turkish Linguistic Society in 2000; Diplomalı Kız novel published in volume named Novels XII (Prepared by: Erol Ülgen, M. Fatih And1, Kazım Yetiş) published in 2003, and Çingene named novel (Prepared by: S. Emrah Arlıhan) published in 2012 by Sel Yayıncilik were analyzed.

\subsection{Analyses of data}

Relation of the data obtained during the classification stage of the study with lifelong learning was found in two respects. First, novel heroes being implementers of the lifelong learning by idealizing them; second, author making the reader a subject to lifelong learning through dialogue method.

\section{Findings}

\subsection{Lifelong learning through idealized characters}

For Ahmet Midhat, sole purpose of being a writer is social benefit. In order to actualize this goal, while writing writings, pieces in fields like education, pedagogy, sociology, psychology, he also tries to realize this manner in literature characters also as much as this type allows him. One of the methods of this teaching manner in his novels and stories is his effort to idealizing the heroes. These individuals; generally presented as positive characters, are hardworking, honest, role models who can establish mind-emotion balance who are appreciated by people around them in their personal lives.

In this section, before going into analyses of novel characters, short information about the subjects of the novels must be given.

Summary of the novel named the Gypsy in short is like this: S.ems Hikmet, who is a wealthy young man, arranges a tour with cockboat with family friends towards Kağıthane. There he meets a gipsy girl named Ziba who is as pretty as her voice and he falls in love with her. However, because of rigid social bias opinions of the time he is living in, it is impossible for him to marry her as a rich 
Enser, R. (2016). The model of understanding education and lifelong learning in Turkish modernization of Ahmet Midhat. International Journal of Human Sciences, 13(1), 436-450. doi:10.14687/ijhs.v13i1.3513

man. Şems Hikmet, as the result of a plan he made secretively from his family, places Ziba in the house of a family friend named Lady Düriye with the permission of the girl's family for her to be raised there. Ziba, by getting a good education there, becomes a person who has everything an ideal lady can possess. Şems Hikmet's mother Ferazende and his uncle Rakım learn about Hikmet's plan and violently object to it. According to them, it is impossible for Ziba, who is a gipsy girl, to be brought to the mansion as a concubine or a wife. Şems Hikmet, who cannot find a solution, finally kills himself.

Main hero of the Gipsy novel, Şems Hikmet is also one of the characters given by idealization. "SSems Hikmet is the son of the deceased Nimetullah, one of the Egyptian merchants. Although his father left him as an orphan at the age of four, since his mother, Ferazende, who is a servant type, is a very thoughtful woman, she raised her son and her daughter Fatma Münevver, who is two years younger than her son with very good upbringing, and also, did not fritter away even a drop of big wealth left from his father, but made real estate investments gaining more than hundred and fifty lira income per month. Education she gave to her son and daughter is not school education. While she had them learn Turkish, Arabic and Persian by having Selimcan Hindi at her house, Selimcan taught perfect English to the child and Şems Hikmet learned French as much as English by himself. He is a lenient child like a diamond, with good morals, taking ownership of his possessions, obedient to his mother's and Selimcan's orders in his actions and manners. "(Ahmet Midhat Efendi, 2012:10-11).

Ideology wise being in a search for a synthesis between East and West, Ahmet Midhat tries to show this synthesis in the characters he idealizes in his fictional texts. In some way he believes that the scale of success both in personal and social life is tied to being able to establish this balance.

Şems Hikmet is a concrete example of the belief above. Besides education in linguistics, he also took music lessons from their family friend, Davut; he is able to play the piano and zither. Şems Hikmet to learn English and French besides Arabic and Persian, his playing the piano which is an instrument that belongs to Western music besides the zither which an instrument that belongs to Eastern music is an indicator of his synthesis idea.

Şems Hikmet is a wealthy person. However, he is not one of the billionaires who spend life in delight and entertainment, not being involved in any kind of production. He spends most of his time in the library of his house; he reads, he produces. Sometimes he publishes what he wrote on his uncle Rahim's newspaper. He is a versatile person who is also interested in hand crafts besides his intellectual pursuits. His this status is explained like this in the novel: "He spends most of this time at the book room with his tutor, Selimcan. He also has an atelier with all the tools related to carpentry, forging and few machines like band saw, powered auger, smoothing machine, turning lathe, making it be like a little factory, the young man makes everything from artsy locks to consoles. He even made a nice chair once." (Ahmet Midhat, 2012: 49).

While Şems Hikmet's cockboat is described, his knowledge and experience on this subject is emphasized. The cockboat he uses "is not a coxswain like the ones owned by some gentlemen who like cockboats." Because Şems Hikmet "is not one of the gentlemen who will turn a thing called pleasure into danger." (Ahmet Midhat, 2012: 8).

By expressing that Şems Hikmet thought of all the details of the shape and features of the sailboat and designed it accordingly in this and in the below expressions, he aimed to show that he has high taste and deep knowledge in this subject as in many other subjects.

"Did you find the sail contradictory to seriousness of Şems Hikmet? Don't rush. Şems Hikmet did not add more sales than what is cockboat could handle for it to go faster. Since he divided the sale to two poles to balance the total wind strength that will be loaded on the boat, he has sail opened 
Enser, R. (2016). The model of understanding education and lifelong learning in Turkish modernization of Ahmet Midhat. International Journal of Human Sciences, 13(1), 436-450. doi:10.14687/ijhs.v13i1.3513

only on one pole when there is too much wind, during less windy weather he lets sails on both poles be cast off.

Also, since his sales are in Latin shape they are suitable to most winds. However, danger of riding in totally opposite winds is not written on Şems Hikmet's map." (Ahmet Midhat, 2012: 9). Actually here, besides explaining that the hero has ideal knowledge, it can be said that at the same time the features a good cockboat must have is aimed to be explained to the reader.

Things Şems Hikmet does for Ziba in the novel is not only because of the love he feels for her. Just like Ahmet Midhat, he thinks of raising him as an idealist character who believes in a humanist progressive idea. The opposite character of Şems Hikmet in the novel is Rakım. The author, by comparing the thoughts of these two characters, also shares his own thoughts related to the subject with the reader in a way: "Just like the Odysseus and Iliad novels of the old times, if our novel is also read for few thousand years, the male and female readers of that time will appreciate and approve Şems Hikmet without a doubt and will blame Rakım for being narrow minded, having short vision, being a bigot. Because, consciousness of human kind will be fully settled by those times and the whole humanity will be the citizen of a single civilization with each individual; and civilization will be globalized so much that there will be no difference between people regarding civilizations or clans. World will be considered as a single country of people and people will be considered as from a single civilized race! This is how Şems Hikmet, when he decided to train a gipsy girl to turn her into a lady, fell into this aim because the felt himself in a mental responsibility of a man who will come on this earth a few thousand years later." (Ahmet Midhat, 2012: 89).

At times, Ahmet Midhat looks for suitability when selecting names for the characters. Şems means the "sun", and metaphorically expresses light, to be enlightened with knowledge. Hikmet, on the other hand, means "wisdom". In the novel, Şems Hikmet is an intellectual person with a settled character despite his young age and the education he received. In the novel also, when referring to Şems Hikmet, he is described as a young man "whose head is enlightened with science and philosophy" (Ahmet Midhat, 2012: 8).

Davut who gives musical education to Şems Hikmet is also idealized occupation wise. "Graduated from Enderun-u Hümayun (Special Imperial School), he is at the level where he not only reads and plays a song with musical repertoire already prepared, but is also at the level of creating a new composition to given lyrics. He blows on the reed flute well. He plays the violin wonderfully. $\mathrm{He}$ is not even deficient in the piano. On the contrary to most of our musical experts, he also knows musical notes perfectly. His ties with Şems Hikmet are due to giving lessons to him and his sister. However, not for a five ten Lira a lesson like other experts. Maybe a lesson given because he is an old friend of the family, and isn't the real wisdom in this?"

Davut to be able to play musical instruments of the East and the West, in addition, for him to know the musical note system which is the education type of the west is explained by assuming this as an example of synthesis search of Ahmet Midhat, mentioned above: "Davut is not a type of musician who understands nothing from European music, he has realized that some European modes are same as our rast mode and some even are as same as nihavent mode. He even has efforts to spice up Turkish music by taking some tunes from European to put into Turkish." (Ahmet Midhat, 2012: 20).

When Şems Hikmet takes Ziba to Lady Düriye's house where she will be educated in, the girl tries to kiss Lady Düriye's skirt like polite people. When Ziba actualizes this request in fully in-line with etiquette, this conversation takes place between Şems Hikmet and Lady Düriye:

-Well, polite girls either kiss the hand or the skirt of ones older than them as a sign of respect. Bravo Ziba! You kissed a skirt so well that it made me simply believe you will accept to learn good manners. 
Enser, R. (2016). The model of understanding education and lifelong learning in Turkish modernization of Ahmet Midhat. International Journal of Human Sciences, 13(1), 436-450. doi:10.14687/ijhs.v13i1.3513

\section{Lady Düriye:}

- Why shouldn't she accept it my son! Praise be, what a beautiful girl? These kind of girls are usually smart also. Let me teach her manners and you will see if you find her with better manners than the gentle girls or not? (Ahmet Midhat, 2012: 56).

Ziba stays in Lady Düriye's house for one year. Here she also takes violin lessons besides learning to cook, present food, eating etiquette, rules of etiquette, customs and traditions of noble people and she is extremely eager and successful in all of them. She finally turns into a completely polite lady regarding her manners, clothes and physical appearance.

Author defends the belief that if equal opportunity, one of the basic laws of education, is followed, adult individuals can develop themselves at every stage of their lives, can become respectable individuals by fulfilling the requirements of the time living in and thus spending a happier life both in individual and social means will be possible.

The objective for Ahmet Midhat to choose a subject evolving around a gipsy girl in this novel is to draw attention to race discrimination. In the $19^{\text {th }}$ century Ottoman where no class disputes happen and there are no serious problems with this but rigid class prejudices dominate, it is pleaded with the through this topic that these problems can be solved by logical reasoning. Besides this, he tries to relay that no matter from which race or social class; each individual can learn many things in every stage of life and can turn this into a value in his/her life and thus can be a happy individual.

Seen in the novel that he shares the same thoughts as the author, Şems Hikmet says like this while talking about his plan regarding Ziba with his tutor Selimcan before he implements is: "They say 'the twig is bent, while it is wet' and it really is true. Yet, developments in the industry found ways to also wet a dry tree and bend it by putting it close to fire. Especially when they are wetted with vapor, even the thickest ones are bent. If we also think of human education in line with disciplining of the tree, than we cannot be content with just saying "the twig is bent while it is wet". We will be proud of our strength in the subject of discipline by saying "All trees can be bent at any time"' (Ahmet Midhat, 2012: 32).

With the 'tree' and 'bending' metaphors in 'every tree can be bent at any time' expression, it can be said that by saying that education can be and must be possible at every stage in every individual's life and at anywhere, the basic logic of lifelong learning is emphasized conceptually.

In his novel, Girls with a Diploma, on the other hand, a poor family's struggle to have their daughter get educated under difficult conditions is being handled. Jean Depres, living in the attic with his wife and daughter and working as a hammer man, does everything in his power for his daughter to get a good education despite his wife's disputes and difficult economic conditions and has his daughter go to school up to "maârif-i intihâiye" (final school). However, with the addition of his illness the family falls into very difficult state. The girl, even though she graduated from a teacher school, cannot find a job anywhere because of changing life conditions. Afterwards, she starts selling flowers by keeping as a secret from her family. She generates a significant group of customers with her education while she sells flowers in front of a theater during evenings. She rents a nice flat for her family with the money she saves and they continue their lives in prosperity.

It can be said that in Ahmet Midhat view of education, learning transforming into a value in individual and social means which is the one of the fundamental objectives of lifelong learning is dominant. Just like in the learning processes of Canan in Felatun Bey İle Rakim Efendi, of Ziba in Çingene, the education Julie, in Diplomalı Kız, received turns into a value both in her individual life and in her family life. In Julie's father's determination to get her educated, he expresses that the investments done on a person's education returns back to the individual and the society (to her family in the novel) more strongly with some pragmatist point of view like this: "We should not consider whatever we spend for Julie now as an expense. It must be considered as savings, 
Enser, R. (2016). The model of understanding education and lifelong learning in Turkish modernization of Ahmet Midhat. International Journal of Human Sciences, 13(1), 436-450. doi:10.14687/ijhs.v13i1.3513

retention. Because it means we are loaning those money to the girl. And its interest is processing. The interest is Julie's advancement. After Julie completes her education, she will give back what she took from us together with the extras. When we get old, we will reach benefaction and happiness!" (Ahmet Midhat, 2003: 20).

The most important person expressed by idealization Felatun Bey İle Rakım Efendi. Rakım lost his father at a very young age and then his mother afterwards. He is living with his Governor Overseer Fedai. His governor and his mother, while she was alive, die everything in their power for him to finish his education. He works to earn his living at an early age because of hard living conditions.

Rakım is very eager and hardworking on developing himself. He goes to madrasah (Muslim theological school) in Süleymaniye on one hand, tries to learn French after he leaves there by a clerk, from there he goes to a doctor's office in Galata to work to further improve his French. In addition, he reads French books for hours by shutting himself in the library of a Foreign Affairs Office by teaching Turkish to an Armenian friend of his there. ${ }^{3}$ He is even such a curious person that he spends a whole day by himself at one of his friend's house when there is no one else there.

This desire of Rakım to read and to develop himself is explained in the novel like this: "The discipline and education Rakım received is such that a child of many well-endowed men cannot achieve. With his own desire and his governor's incitement and motivation, he learned from Arabic grammar rules from Sarf u Nahiv and Risale-i Erbaa books. He learned logic lessons to the end. He reached a very good place at the sciences of Hadith and Interpretation. He also worked on science of Islamic Law. He also examined Gülistan and Baharistan and Bustan and Pendi-i Attar and Hafiz and Saib one by one and did not refrain from memorizing the important pieces. When it comes to French, he ensure success by going very deep in French language and learned about sciences of nature, chemistry and medicine from a friend of his in Galata and got educated on these subjects. He learned information of geography, history, law and history of governments at the library of his Armenian friend in Beyoğlu. Especially, it seemed like there was no end to the French novels and theater words and literature knowledge he read. If he was able to get a permission to take a book home to keep with him for two nights, he wouldn't only read it, he would make copies of their best parts. "4 (Ahmet Midhat, 2000:12-13).

Rakım's circle of friends is mostly foreigners. Rakım does all translations within this circle and ears good money. He also gives Turkish lessons to Can and Margrit who are the daughters of an Englishman named Mister Ziklas. He develops a teaching method for himself and girls improve their language level in a short time. He also establishes good relations with the family.

\footnotetext{
${ }^{3}$ Rakım portrait Ahmet Midhat draws carries marks from his own life. In his memories he explained in exile, he takes French lessons from an Armenian friend of his named Dragan. He also expresses that Odyan who is a Danube politics officer made him read many French books (Ahmet Midhat, 2013: 14-15). Again in Niece, he significantly benefits from the knowledge and rich library of Mr. Sakir who is the Head of the Immigration Committee. (Okay, 2008: 23)

${ }^{4}$ In lifelong learning, aim is for individuals to develop themselves according to needs of that time period and for them to be able to overcome the problems they will face by themselves. Individuals and societies face various requirements in every period. Since Ahmet Midhat believed the fundamental problems of the time he lived in was wrong Westernization, he defends the necessity for individuals to understand the period by protecting their own national identities and for them to act according to the period they live in. In the analyzed novels also, certain characters materialize this belief as prototypes. Rakım knows French, Arabic and Persian. He is educated at Madrasah (Muslim theological school), he has wide knowledge of religious information; besides this, he also develops himself on the subject of positive sciences. He reads both Eastern Classics, and follows modern French literature. Ahmet Midhat's understanding of synthesis shows itself in Rakım's learning style. Rakım is an ideal person who is able to succeed this synthesis. In the novel based on double hero structure, Mr. Felatun is situated across of Rakm as a negative character. Mr. Felatun is a spendthrift. Even the education he got is superficial; he doesn't feel the need for it. He runs after pleasure and entertainment. Rakım, on the other hand, works non-stop and pays efforts to develop himself. His success is for him to learn new things and develop himself as a person suitable for the period by protecting his own identity.
} 
Enser, R. (2016). The model of understanding education and lifelong learning in Turkish modernization of Ahmet Midhat. International Journal of Human Sciences, 13(1), 436-450. doi:10.14687/ijhs.v13i1.3513

Another person explained by idealization in Felatun Bey Ile Rakım Efendi, is Canan. Canan is a Circassian concubine Rakım took by feeling sentimentally close when he first saw her and the girl he will marry. Rakım, when he began to give Turkish lessons to English girls, he also begins to give lessons to Canan at the same time. She advances very rapidly from the first week on with her intelligence, curiosity and desire for learning. Although internal time is not mentioned in the novel she learns Turkish in a few months, "Not just as it is required but thoroughly." (Ahmet Midhat, 2000: 39).

Canan's curiosity for learning is not just limited to this. Rakım's neighbor has his concubines take piano lessons. Governor Fedai, thinking that Rakım may not give permission, gives Canan permission to join these lessons. When Rakim finds out he does not find it right for Canan to take lessons in someone else's house and he promises the girl that he will buy her a piano and hire a teacher for her. However, his financial situation is not really suitable for his to do these.

When Rakim explains this situation during a conversation in one of his French friend's house, he finds out that the teacher who gave lessons to Canan is also there. This French woman, named Josefino, says she is very happy from Canan's performance and reproaches Rakım because she is not able to come to lessons anymore. Josefino tells Rakim, if he buys a piano for Canan, she would give lessons free of charge to her old student Canan whom she loves very much. This way Canan begins to take piano lessons again.

In addition, Josefino starts to teach the girl French to be able to communicate better with her. Rakım gets very happy when he hears this. But he starts giving French lessons himself to her for the learning to be more systematic. Rakım, even begins to teach the girl Arabic and Persian according to his teaching method.

Canan is very smart and has that much desire for learning. This is explained in the novel like this: "The girl's intelligence was so high that, when Josefino saw that a lesson she describes once is done by the girl so well without another explanation, she is baffled and therefore she began to increase her conversations with the poor girl more and more." (Ahmet Midhat, 2000: 42).

Ahmet Midhat defends in every opportunity that equal opportunity is a must both in regards to gender and to social status. In the novel also, while Rakim implements lifelong learning with selfmotivation, Canan shows how successful one can be in fields like music, linguistics if equal opportunity is provided.

\subsection{Lifelong learning through dialogue narration with the reader}

Ahmet Midhat, adapts dialogue narration as a characteristic manner and uses this in almost all fictional texts. Ahmet Midhat's dialogism is his talking directly with the reader, and even including the reader in the fiction of the text. Author himself is also included in the text; because the narrator and the author are identical most of the time. It can be said that the author's adaptation of this style is affected by the public storyteller tradition technically. In the beginning of $19^{\text {th }}$ century Ottoman society when novels and stores were not written yet in modern means, public storyteller tradition continues its existence and impact in narration concept.

Ahmet Midhat's objective in using dialogue manner in his texts is the approach of the reader, who just met the novel which is a new type of writing in Western means, to the text, in other words, preventing the text to become estranged. Using the talking manner used in traditional public storyteller narration in the writing language will be more appealing to the reader and the reader will get used to this new type faster. Therefore, it can be said that for Ahmet Midhat to adapt his type of manner is deliberate. Another impact is Ahmet Midhat's teaching character. As also mentioned before, trying to learn everything with big desire and curiosity since childhood, the author has been in the effort to give what he learned to the reader in the means of getting informed, development 
Enser, R. (2016). The model of understanding education and lifelong learning in Turkish modernization of Ahmet Midhat. International Journal of Human Sciences, 13(1), 436-450. doi:10.14687/ijhs.v13i1.3513

and awakening. This attitude has also reflected on the author's writing manner. He thinks of the reader pretty much as a student listening to a lesson in front of him.

Author tries to transform the dialogue he continues to use with the reader into a learning platform. Author who tries to research, learn with big curiosity, tries to share this with the reader at most suitable opportunities. This learning-teaching (regarding the author), learning (regarding the reader), shows lifelong learning is targeted as the most important feature of Ahmet Midhat's fictional texts.

One section from the beginning of the novel named the Gipsy is one of the most typical examples of this. By giving the date and place of the event at the beginning of the novel, he gives some general information about his place, then puts the reader in place of the novel heroes he hasn't mentioned yet. He takes them on an "imaginary" tour:

He says, "Imagine you are going to Kağthane through the sea. A port with both sides surrounded by vast lands of a big capital is on the route you will follow..." and he gives descriptive information about the appearance of Golden Horn in those day and continues: "Golden Horn begins to get narrow as you get closer to Kağtthane. It gets narrower and also the dark blue water begins to lighten up. It gets lighter and lighter and at one time takes on a greenish color. It starts getting yellow. Finally, the Golden Horn stops being a port and starts to become a wide river.

But it is not a river yet. We didn't reach Kağthane stream yet. We are in front of Eyüp. (...) Our boat is still moving forward. Just when you reached where Alibeyköy stream and Kağithane stream joint, the place really took on a river scenery view. Since you are going to Kağıthane, you leave Alibeyköy stream on your left and point your boat to the stream on the right." The reader's boat tour continues. Author, like a tour guide, talks about the natural beauties, historical pieces and gives information about them. Boat ride ends but the author's and the reader's tour continues: "We could not have shown you all the surrounding beauty of Kağtthane by taking you to Çaglayan." After that he turns to the novel's heroes and begins to introduce them to the reader.

In the novel, in the section where Mr. Davut begins to give Ziba violin lessons, Ziba's skills on this are mentioned. Then the author, by getting out of the event grit, gives information of the characteristics of violin which is a fretless instrument and the difficulties of playing the violin: "Since it came up, wouldn't it be right to show this difference in more detail? Probably, most of the readers don't know this difference.

Since each fret, made of bone, in stringed instruments like piano and harmonica, give out the sound unique to it fully, there is never a solid sound problem in these types of instruments. Although Frets tied with violin string or metal string with knots on top of fretters of stringed instruments like tambura, lute, cannot, in reality, achieve to give out a solid sound at the level of piano or harmonica, and need the expertise of the person playing it, it would probably facilitate to point which sound will come out of where. On the violin, however, there is no sign anywhere. Fretter is open all the way. It is such a skill to instantly find where each sound will come out from, it is even hard for forty year violinists to not make mistakes at this point although at a level the listeners will not notice. It's not possible to identify where a sound will come out from the violin fretter. Fingers need to get accustomed. But, no matter how much fingers get accustomed, the real skill is in the ear. Diameter of one finger takes up such space that there will be half fret difference between the sounds that come out if one side is pressed more and the other side is pressed more. Thus, the experience a violinist ear understands the excess or lack of the sound it will give out as soon as he starts and brings out the sound fully by turning his finger from one side to the other." (Ahmet Midhat, 2012: 63-64).

During the boat ride made at the beginning of the novel, while talking about things on the boat at that time, information on number thirteen is given to the reader by leaving the flow of the topic: 
Enser, R. (2016). The model of understanding education and lifelong learning in Turkish modernization of Ahmet Midhat. International Journal of Human Sciences, 13(1), 436-450. doi:10.14687/ijhs.v13i1.3513

"People on the boat reach thirteen together with the storekeeper. Europeans believe this number thirteen to have bad luck. When thirteen people get together like this on a boat, a table, in short wherever, they either let one person go or get another person to bring the number to fourteen. We can't know whether there is really bad luck or not. We just know that the bad luck in subject belong to Europeans and even among us, believing this is considered to be European. There is a possibility there are some clans in the world who believe number thirteen to be very lucky. If ones who are afraid of bad luck of this number face some bad luck or believe it to be lucky and reach happiness, it would be more right for them to find the impact not on the number but on their belief. Now, let's follow our boat." (Ahmet Midhat, 2012: 14).

Name of the first section in the Girl with a Diploma is "Mansardda". Author gives information on this word to the reader before even getting into the topic:

"As you know, snow on the attic of the houses is called 'mansard' (mansarde). In order to not leave the space in the middle of the roofs where it is a bit high, people make few rooms there and rent them out to poor people. Anyway, what would a well-off person do there? In Europe, the best floors of houses are their first floors so it is easy to go up and down. The rent prices of rooms as going up to second, third or higher floors go down. The lowest rent price is paid to the mansards which are the rooms at the highest floor. Likewise, their ceilings are very low and windows are nothing but a 'hole'. Our readers of course understood that these are public residences with each room, each flat of these houses we are mentioning with rooms on many floors are rented to a different tenant." (Ahmet Midhat, 2003: 301).

Author-narrator, says he is keeping it short here since he gave detailed explanation on the subject in his text named A Tour in Europe. Ahmet Midhat, by creating organic binds between the texts he writes, wants the readers to perceive these pieces as information sources to look up at when necessary.

In continuation of the novel, while mentioning about Jean Depres's occupation, he gets into a dialogue with the reader on the subject: 'Do you know what 'Varyoz' is? You know the big hammers two hammer men stand across from each other and forge irons as thick as an arm or a leg on big anvils? That's it. Being a hammer man in hammer smith craft needs both strength and expertise." (Ahmet Midhat 2003: 305) Narrator, in continuation, gives information to the reader on how hammer men forge the iron, details of this occupation and how much these people earn both in Paris and in his own country.

In Mr. Felatun and Rakım, the narrator talks about Mr. Felatun's interest in having the books he buys get bonded and says he prints letters $\mathrm{A}$ and $\mathrm{P}$ on them. Than the narrator calls out to the reader and explains about the subject: "You know these two words in French? One is medli elif, the other is 'P' letters. First is the first letter of Mr. Ahmet Felatun and the second it the first letter of word Platon which is what Felatun is called in French. In Europe, firs letters of a person's name or names are put and this is called that person's 'brand'." (Ahmet Midhat, 2000: 131).

As can be seen, author-narrator is making direct explanations by cutting the flow of the topic with the thought that the reader may not have knowledge on the subject. One of the main reasons of this is Ahmet Midhat perceiving learning to come before entertainment. Ahmet Midhat, because he lived in an age when formal education is not fully spread out, one of the biggest problems for someone is to access information, tries to use every opportunity by forcing the facilities of fictional texts. Since similar examples to the ones given above will really exceed the limits of the study, these will be sufficient.

\subsection{Lifelong learning through the moral of the story}

Ahmet Midhat tries to get a moral of the story in his fictional texts with also the impact of storytelling tradition. Also in the Çingene, Diplomalı Kız novels, which were subjects to this study, 
Enser, R. (2016). The model of understanding education and lifelong learning in Turkish modernization of Ahmet Midhat. International Journal of Human Sciences, 13(1), 436-450. doi:10.14687/ijhs.v13i1.3513

he clearly explains the morals to be extracted from the story by getting into a dialogue with the reader. There is an epilogue at the end of the novels in subject. There is no such section in Felatun Bey İle Rakım Efendi. Although this deductive manner is criticized, since the author thins his readers are not people with high literature tastes, they are ordinary individuals who recently learned to be literate, he really did not pay attention to these criticisms.

In Çingene novel, Ziba who is a gipsy girl becomes a very attractive and dexterous lady due to the education she received. Her new state is also appreciated by most of Şems Hikmet's family friends; but when his mother Ferazende and his uncle Rakim learns what he did and his plan to marry Ziba, they violently oppose this. There is no logical reason for their opposition. They don't accept this situation as a bourgeoisie reflex that defends strict social order. Şems Hikmet cannot envisage having the whole social structure against him and tries to commit suicide; he has a brain concussion. Şems Hikmet's mother, thinking that it would help, asks Ziba to come to the kiosk to have her see her son, but Şems Hikmet is in such a bad condition that he doesn't recognize Ziba. Few days later he passes away.

Ferazende and Rakim, when they see the change in the girl as the result of the education she received and her devotion to Şems Hikmet, realize they are wrong. Ferazende loves Zida as her own daughter and they live together at the kiosk. And Ziba, by staying devoted to the memory of Şems Hikmet who loved her so much, doesn't get married again.

Author tries to explain that learning is not only limited to formal education, but also the lessons taken from the negativities lived in life are each forms of learning in the "moral" section of the novel. He writes his thoughts on reaching the good, the right way by benefiting from others' experiences in traditional moral of the story concept and tries to give it to the reader in a novel platform. Finally, his makes Rakim say, "if they vaccinate a wild sapling with expertise, it is possible to get the desired result" (Ahmet Midhat, 2012: 97). This is Rakım's thought but it has no respondent in the fiction because it is directly being told to the reader.

Events happen in Paris in the Diplomalı K $1 z$ and subject is education of girls. In the "epilogue" at the end of the novel it is said like this: "Even if she is selling flowers, girls must be disciplined and educated." Narrator-author explains the subject of education of girls is valid for all countries, girls have as much right for education as boys, and that he believes, and in the future women will catch success in all occupations. It is extremely significant for these words to be said in 1890's.

\section{Conclusion}

Lifelong learning has become one of the principal concepts of education policies in especially Europe since the last half century. Rapidly aging European population also brought some problems in subjects of advancement and innovation. With this objective, with lifelong learning, by making education continuous, aim is to have individuals be in line with the age and thus contributing to their personal happiness and making production continuous.

Ahmet Midhat, who lived in a period when the Ottomans were facing very big problems in political and economic fields and when modernization acts had increased to save the country from this difficult situation, also began to search for solutions to these problems as an intellectual person. Especially aspiring from experiences in his own life experiences, he believes personal happiness and social development go through education. As in his newspaper articles and in his books written in different topics, he defended the thought that there is a significant tie between the education and development of individuals and fundamental problems the country is facing and development.

Ahmet Midhat; by also putting priority of education of the individual in his Çingene, Felatun Bey İle Rakım Efendi, Diplomalı Kız novels, by defending that education must be at every stage of life and everywhere for everyone, tried to give lifelong learning in fiction in respect to basic contents of the concept although it may not be conceptual. 
Enser, R. (2016). The model of understanding education and lifelong learning in Turkish modernization of Ahmet Midhat. International Journal of Human Sciences, 13(1), 436-450. doi:10.14687/ijhs.v13i1.3513

In the novels examined in this study, it is found that Ahmet Midhat tried to handle lifelong learning within the limits of fictional texts and has done this in three ways. First, idealizing the novel individuals, who adopt lifelong learning as an objective at the level of meaning for them, to set examples to the reader. Second; author including the reader in the text context by establishing direct dialogue with the reader, and giving information to the reader about the subject, by interrupting the flow of the events. It can be said that for the author to benefit from the storytelling tradition and thinking being a writer as a schools has a significant role in this. Third; Ahmet Midhat, using the moral of the story concept by again benefitting from the storytelling tradition and his writing the moral at the end of the texts. It can be said that the author aims for the reader to relate the fictional text with the real life.

Although subject of education is as old as human history, for Ahmed Midhat to struggle for education of individuals to ensure individual prosperity and social development and for it to be a fundamental policy shows that he realized lifelong learning more than one hundred years ago which shows how important the author is for the life of Turkish literature and thought.

\section{Refferences}

Ahmet Midhat Efendi (2012). Cingene (Pr.by: S. Emrah Arlihan). İstanbul: Sel.

Ahmet Midhat Efendi (2003). Haydut Montari, Diplomah Kı₹, Gürcü Kı‡̨ Yabut Intikam, Rikalda Yabut Amerika'da Vahşet Alemi, (Pr.by : Erol Ülgen, M. Fatih Andı, Kâzım Yetiş). Ankara: Türk Dil Kurumu.

Ahmet Midhat Efendi (2000). Dünyaya ikinci gelis yahut İstanbul'da neler olmus, Mr. Felatun Bey İle Râkım Efendi, Hüseyin Fellâh, (Pr.by : Kâzım Yetiş Necat Birinci, M. Fatih Andı). Ankara: Türk Dil Kurumu.

Ahmet Midhat Efendi (2013). Menfa, sürgün hatralar, (Pr.by: Handan İnci). İstanbul: Kap1.

Albayrak, L. (2010). Ahmet Mithat Efendinin eserlerinde eğïtim ve çağdaş eğitim yaklaşımlar arasinda bir karşlasstrma. Unpublished Doctorate Thesis, AtatÜrk University, Institute of Social Sciences, Erzurum. Adopted from https://tez.yok.gov.tr/UlusalTezMerkezi.

Brooks, G. \& Burton, M. (2008). European adult learning glossary, Level 1. Retreived October 15, 2015. from https://ec.europa.eu/epale/sites/epale/files/adultglossary1 en.pdf

Commission of the European Communites (2006). Adult Learning: It Is Never Too Late to Learn. Brussels, 23 October, Com (2006) 614 Final. October 15, 2015. from http://platformlearnforlife.nl/documents/bv-iccommunicationectekst.pdf

DPT (2001). Sekiz̨inci bes ynllhk kalkinma plan: hayat boyu eğitim veya örgün olmayan eğitim özel ibtisas

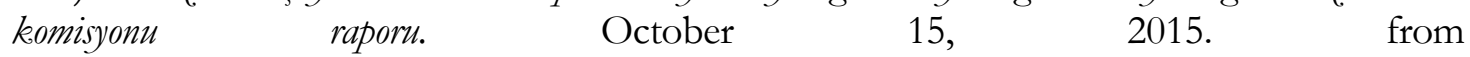
http://www.eduser.com.tr/upload/dosya/34._dpt8.kalkinmaplanihayatbo.pdf

DPT (2009). Hayat boyn ögrenme strateji belgesi. October 15, 2015. from http://mesbil.meb.gov.tr/genel/hayat $\% 20$ boyu $\% 20 \% \mathrm{C} 3 \% \mathrm{~B} 6 \% \mathrm{C} 4 \% 9$ Frenme $\% 20$ dokuma n.pdf

Tanpınar, A. H. (1988). 19uncu Asır Türk Edebiyatı Taribi, İstanbul: Çağlayan.

Koç, O. (2009). "Toplumsal Değlişim Sürecinde Abmet Midhat Efendi'nin Eğitim Anlayzşıı", First International Symposium Sustainable Development (ISSD'09) June 9-10, 2009, Bosnia and Herzegovina

Moran, B. (1998). Türk Romanma Eleștirel Bir Bakeıs-1, İstanbul: İletişim.

Okay, O. (2008). Batı Medeniyeti Karşısında Ahmet Midhat Efendi, İstanbul: Dergâh.

Özön, M. N. (2009). Türkẹede Roman, İstanbul: İletişim.

Toprak, M. \&Erdoğan, A. (2012). Yükesekögrretim ve Bilim Dergisi/Journal of Higher Education and Science. Volume 2, Pages 69-91.

Us, H. T. (1955). Bir Jübilenin Intibalar: Abmed Midhat' Anyyoruz, İstanbul: Vakit.

Yazgiç, K. (1940). Ahmet Midhat Efendi: Hayatı ve Hatıraları, İstanbul: Tan. 